\title{
A Study of Insulin Binding Sites in the Chicken Tissues
}

\author{
J. Simon', P. Freychet ${ }^{2}$, and G. Rosselin ${ }^{3}$ \\ ${ }^{1}$ Station de Recherches Avicoles (Institut National de la Recherche Agronomique), Centre de Recherches de Tours, Nouzilly, \\ ${ }^{2}$ Groupe de Recherches sur les Hormones Polypeptidiques et la Physiopathologie Endocrinienne, U. 145 (Institut National de la Santé \\ et de la Recherche Médicale), Faculté de Médecine, Nice, ${ }^{3}$ Unité de Recherche de Diabétologie et d'Etudes Radioimmunologiques \\ des Hormones Protéiques, U. 55 (Institut National de la Santé et de la Recherche Médicale), Hôpital Saint-Antoine, Paris, France
}

Summary. Specific binding of chicken and porcine insulin was demonstrated in isolated chicken hepatocytes, chicken liver plasma membranes and chicken erythrocytes. In the liver, the binding reaction was characterized by a sensitivity and an apparent affinity which were similar to those observed in rat liver and, in contrast, by a decreased number of binding sites. In chicken liver, there were about 5 times fewer binding sites per mg of membrane protein or per unit of cell surface area than in rat liver. In chicken erythrocytes, the number of insulin binding sites per cell was even lower than in chicken hepatocytes. This decreased insulin binding was not accounted for by a faster insulin degradation in chicken tissues. Glucagon binding sites also appeared to be less numerous in chicken than in rat liver, at least at low glucagon concentration; however, the decrease in maximal binding capacity in chicken liver involved insulin and not glucagon binding. That chicken cells are equipped with insulin receptors which are less numerous than in mammalian cells may explain, partly at least, the physiological state of insulin resistance observed in the chicken.

Key words: Insulin, glucagon, binding sites, receptors, liver plasma membrane, hepatocyte, erythrocyte, chicken, rat.

In the chicken (and in birds in general), carbohydrate and lipid metabolism and their hormonal control differ somewhat from those which operate in mammals (for reviews, see [1] and [2]). For example, liver is the site of lipogenesis and the role of adipose tissue is mainly restricted to the storage and release of fatty acids [3-6]. The basal blood glucose level of the chicken is twice that found in mammals. In the chicken, exogenous insulin at doses of $0.5-2 \mathrm{U} / \mathrm{kg}$ body weight, decreases blood glucose by
$25-50 \%$ and increases simultaneously the glycogen content of the liver [7]. After partial or total pancreatectomy, chickens $[8]$ and ducks $[9,10]$ generally develop severe hypoglycaemia in the fasting state, although they also exhibit impaired glucose tolerance. Therefore, birds appear to be mainly dependent on glucagon in the starved state, while remaining dependent on insulin in the fed state. Earlier studies [1] have reported that very high doses of mammalian insulin (up to $500 \mathrm{U} / \mathrm{kg}$ body weight), which are normally lethal in mammals, do not induce convulsions or kill chickens, thus suggesting that the avian species is insulin "resistant". The differences observed in carbohydrate and lipid metabolism between chickens and mammals cannot be accounted for by decreased responsiveness of the chicken B-cell to nutrients (11-13, and J. Simon, unpublished data) or by decreased potency of endogenous insulin. On the contrary, chicken insulin (and turkey insulin which possesses the same amino acid sequence as chicken insulin) are more potent than other insulins studied [14-16]. Chicken insulin also appears more potent than bovine and ovine insulins in lowering blood glucose in the chicken [7].

The primary step in the action of insulin is binding to specific receptor sites on the plasma membrane of target cells (for review, see [17]). We have examined the possibility that an alteration at the level of the insulin receptor may explain some of the pecularities of carbohydrate metabolism and its hormonal regulation in the chicken.

\section{Materials and Methods}

\section{Hormones and Reagents}

"Monocomponent" porcine insulin (lot $\mathrm{n}^{\circ}$ MCS970, $27.2 \mathrm{IU} / \mathrm{mg}$ ) and porcine glucagon (B 66) were gifts of J. Schlichtkrull (The Novo Research Insti- 
Table 1. Response of adenyl cyclase in purified chicken liver plasma membranes ${ }^{\mathrm{a}}$

\begin{tabular}{|c|c|c|c|c|c|c|c|c|c|}
\hline \multirow[t]{2}{*}{ Preparation } & \multirow{2}{*}{$\begin{array}{l}\text { Basal } \\
\text { rate }\end{array}$} & \multicolumn{2}{|l|}{$\mathrm{NaF}$} & \multicolumn{2}{|c|}{ Glucagon } & \multicolumn{2}{|c|}{ Epinephrine } & \multirow{2}{*}{$\frac{\text { VIP }}{20 n g}$} & \multirow{2}{*}{$1 \mu \mathrm{g}$} \\
\hline & & $5 \mathrm{mM}$ & $25 \mathrm{mM}$ & $20 \mathrm{ng}$ & $1 \mu \mathrm{g}$ & $1 \mu \mathrm{M}$ & $10 \mu \mathrm{M}$ & & \\
\hline I & 400 & 1850 & 4750 & & & & & & \\
\hline II & 352 & 2973 & 2253 & 840 & 2995 & 1421 & 1349 & 3057 & 3180 \\
\hline
\end{tabular}

a Production of cyclic AMP is expressed as pmol/mg of membrane protein $/ 15 \mathrm{~min}$, and represents the mean of two determinations

tute, Copenhagen, Denmark). The chicken insulin used was the same as that described previously [14, 15]. Porcine vasoactive intestinal polypeptide (VIP) was a gift of V. Mutt (Biokemiska Avdelningen, Karolinska Institutet, Stockholm, Sweden). Epinephrine was purchased from Calbiochem. Mono ${ }^{125} \mathrm{I}-$ porcine insulin $[18,19],{ }^{125} \mathrm{I}$-chicken insulin [14] and mono ${ }^{125}$ I-porcine glucagon [20] were prepared as previously described.

Carrier free $\mathrm{Na}^{125} \mathrm{I}$ (preparation $\mathrm{I}-\mathrm{S}_{4}$ ) was purchased from Commissariat à l'Energie Atomique (Saclay, France). DEAE-cellulose (microgranular DE 52) was purchased from Whatman, bovine serum albumin (fraction V) from Pentex, bacitracin from Calbiochem, and kallikrein inhibitor (Trasylol) from Specia. Talc tablets (Silicosorbe, $50 \mathrm{mg}$, Dreyfus Herschtel, Paris, France) were used in cxperiments measuring degradation of ${ }^{125} \mathrm{I}$-insulin [21]. Other chemicals were of reagent grade.

\section{Membrane and Cell Isolation}

Highly purified plasma membranes were prepared from livers of fed 4-5 week-old rats $(120-140 \mathrm{~g})$ following the method of Neville [22] and from livers of fed 3 week-old male chickens (IJV 715 or Hubbard breeds, 300-350 g) using the same method, except that the number of strokes in step 2 [22] was reduced to four instead of nine. Membranes were stored at $-80^{\circ} \mathrm{C}$ until use. The suitability of this isolation procedure for chicken liver plasma membranes was tested by measuring the activity of membrane adenylate cyclase [23] under basal and stimulated conditions. Natrium fluoride $(25 \mathrm{mM})$, glucagon $(1 \mu \mathrm{g} / \mathrm{ml})$, epinephrine $(10 \mu \mathrm{M})$ and VIP (1 $\mu \mathrm{g} / \mathrm{ml}$ ) increased the basal activity by 12 -fold, 8.5-fold, 3.8-fold and 9-fold, respectively (Table 1).

Liver cells were isolated from fed 6 week-old male chickens (Hubbard breed) following the method of Capuzzi et al. [24]. Erythrocytes were isolated from heparinized whole blood freshly drawn from fed 1-2 week-old chickens as described by others [25], except that erythrocytes were rinsed 3 times and resuspended in the incubation buffer [26].

\section{Incubation Conditions for Binding Studies}

Studies of insulin binding to chicken and rat liver plasma membranes were conducted at $30^{\circ} \mathrm{C}$ in Krebs-Ringer phosphate buffer, $\mathrm{pH} 7.5$, in a final volume of $0.5 \mathrm{ml}$ per incubation tube that contained ${ }^{125}$ I-insulin at $0.2-0.5 \mathrm{ng} / \mathrm{ml}$, unlabelled chicken or porcine insulin at the concentrations indicated, membrane protein [27], $0.1-0.3 \mathrm{mg} / \mathrm{ml}$ and bovine serum albumin, $15 \mathrm{mg} / \mathrm{ml}$. These conditions are adequate for comparison of insulin binding in chicken and rat tissues since it has been shown that the binding characteristics $(\mathrm{pH}$, temperature, negative cooperativity) of the insulin receptor in erythrocytes and erythrocyte membranes from the turkey are identical to those of the mammalian insulin receptors [28-29]. At the end of incubation, duplicate aliquot samples from each incubation tube were transferred to microfuge tubes and membrane-bound ${ }^{125} \mathrm{I}$-insulin was isolated by rapid centrifugation through a washing buffer, as described previously [30]. Studies of glucagon binding [31] were conducted in the same manner except that the incubation medium contained bovine serum albumin, $24 \mathrm{mg} / \mathrm{ml}$, bacitracin $100 \mu \mathrm{g} / \mathrm{ml}$ and Trasylol $2000 \mathrm{IU} / \mathrm{ml},{ }^{125} \mathrm{I}$-glucagon was about $0.1 \mathrm{ng} / \mathrm{ml}$. After $30 \mathrm{~min}$ at $30^{\circ} \mathrm{C}$, isolation of membrane-bound ${ }^{125} \mathrm{I}$-glucagon was performed as described for insulin [30].

Studies of insulin binding to chicken liver cells [32] were conducted at $30^{\circ} \mathrm{C}$ in $250 \mu \mathrm{l}$ of KrebsRinger bicarbonate buffer ( $\mathrm{pH} 7.5)$ that contained bovine serum albumin $30 \mathrm{mg} / \mathrm{ml},{ }^{125} \mathrm{I}$-insulin about $0.5 \mathrm{ng} / \mathrm{ml}$, unlabelled chicken or porcine insulin, and hepatocytes at the concentrations indicated in figures. The cell concentration was estimated by counting two aliquot samples of the cell suspension in a Malassez chamber. Incubations were stopped by addition of $2 \mathrm{ml}$ of chilled Krebs-Ringer phosphate buffer, $\mathrm{pH} 7.5$, containing bovine serum albumin $10 \mathrm{mg} / \mathrm{ml}$. Cell-bound ${ }^{125}$ I-insulin was isolated by rapid filtration on cellulose acetate (EAWP $1 \mu \mathrm{m}$ ) Millipore filters and rinsed twice with $4 \mathrm{ml}$ of the same cold buffer [32].

Studies of insulin binding to chicken erythrocytes 
were conducted at $20^{\circ} \mathrm{C}$ or $30^{\circ} \mathrm{C}$ in $0.5 \mathrm{ml}$ of the same buffer as that used in studies of insulin binding to human blood cells [26]. The incubation medium contained ${ }^{125} \mathrm{I}$-insulin $0.5 \mathrm{ng} / \mathrm{ml}$, unlabelled porcine or chicken insulin, and erythrocytes at the concentrations indicated. At the end of incubation, duplicate aliquot samples $(200 \mu \mathrm{l})$ from each incubation tube were transferred to microfuge tubes and treated in the same manner as for the isolation of membrane-bound ${ }^{125}$ I-insulin [30].

In all binding studies, nonspecific binding was estimated in simultaneous experiments by measuring the radioactivity bound in the presence of a large excess $(50$ or $100 \mu \mathrm{g} / \mathrm{ml})$ of unlabelled hormone $[18,33]$. The nonspecific binding, expressed as $\%$ of the total binding ${ }^{125} \mathrm{I}$-chicken or porcine insulin, represented $10-15 \%$ in chicken liver plasma membranes, $5-10 \%$ in rat liver plasma membranes, $7-20 \%$ in chicken hepatocytes and $7-15 \%$ in chicken erythrocytes. The nonspecific binding, expressed as $\%$ of the total binding of ${ }^{125} \mathrm{I}$-porcine glucagon represented about $10-15 \%$ in chicken liver membranes and $3-5 \%$ in rat liver membranes.

\section{Expression of Results}

The data obtained in competitive binding experiments were expressed as the percentage of initial binding (i. e., the binding of ${ }^{125} \mathrm{I}$-hormone in the absence of unlabelled hormone, or $\left.B_{0}\right): \frac{B}{B_{0}} \times 100$. This percentage and its logit transformation were plotted against the concentration of unlabelled hormone on an arithmetic scale and on a logarithmic scale, respectively (Logit $y=\log \frac{y}{100-y}$, where $y=\frac{B}{B_{0}} X$ 100). The number of specific binding sites and the corresponding apparent dissociation constants of the hormone-receptor complexes were determined from competition data at steady-state by plotting the amount of hormone specifically bound against the concentration of free hormone. The number of binding sites was also determined by Scatchard and Lineweaver-Burke plots of the same data. Statistical analyses were performed by covariance analysis [34] for the comparison of chicken and porcine insulins.

\section{Results}

Binding of Chicken and Porcine Insulin to Chicken Liver Plasma Membranes.

The time-course of binding of both ${ }^{125}$ I-porcine insulin and ${ }^{125} \mathrm{I}$-chicken insulin to chicken liver plasma membranes at $30^{\circ} \mathrm{C}$ was similar (data not shown) to that observed with ${ }^{125} \mathrm{I}$-porcine insulin binding to rat liver membranes $[19,30]$. With both ${ }^{125} \mathrm{I}$-insulins at $0.2 \mathrm{ng} / \mathrm{ml}$, the steady state of binding was reached after $1 \mathrm{hr}$ incubation at $30^{\circ} \mathrm{C}$. Therefore, the binding of chicken and porcine insulin at steady state was investigated after $1 \mathrm{hr}$ incubation at $30^{\circ} \mathrm{C}$, using either ${ }^{125} \mathrm{I}$-chicken or ${ }^{125} \mathrm{I}$-porcine insulin. The initial binding $\left(\mathrm{B}_{0}\right)$, expressed as \% total radioactivity, was similar with ${ }^{125} \mathrm{I}$-chicken and with ${ }^{125} \mathrm{I}$-porcine insulin: $5.4 \pm 0.1$ and $4.6 \pm 0.1$ (mean \pm SEM, $\mathrm{n}=4$ ), respectively, with membrane protein at $0.27 \mathrm{mg} / \mathrm{ml}$. Both unlabelled insulins competed with the binding of either ${ }^{125} \mathrm{I}$-insulin (Fig. 1). Low concentrations $(1-2 \mathrm{ng} / \mathrm{ml})$ of unlabelled chicken and porcine insulins inhibited $5-12 \%$ of the binding of both ${ }^{125}$ I-insulins. Higher concentrations $(100 \mathrm{ng} / \mathrm{ml})$ inhibited $70-75 \%$ of the ${ }^{125}$ I-insulin binding. At concentrations lower than $100 \mathrm{ng} / \mathrm{ml}$, chicken insulin appeared slightly more potent than porcine insulin in competing with the binding of both ${ }^{125} \mathrm{I}$-insulins. Logit transformation of the data gave significant $(\mathrm{P}<0.05)$ regression lines within a concentration range of $2-40 \mathrm{ng}$ insulin $/ \mathrm{ml}$ (Fig. 1 right). Chicken insulin was significantly $(\mathrm{P}<0.05)$ more potent than porcine insulin when the tracer was ${ }^{125} \mathrm{I}$-porcine insulin.

\section{Binding of Chicken and Porcine Insulin to Chicken Hepatocytes}

The apparent steady state of binding of ${ }^{125}$ I-chicken insulin to chicken hepatocytes at $30^{\circ} \mathrm{C}$ was reached by one hour and was stable for the subsequent $2 \mathrm{hr}$, regardless of the cell concentration (Fig. 2). The specific binding increased with the cell concentration and represented $2.2 \%$ of total radioactivity with $3.6 \times 10^{6}$ cells $/ \mathrm{ml}$ (Fig. 2). Subsequent binding studies were carried out at $30^{\circ} \mathrm{C}$ for $1 \mathrm{hr}$ with about $4 \times 10^{6} \mathrm{cells} / \mathrm{ml}$.

At steady state, the initial binding $\left(\mathrm{B}_{0}\right)$ of ${ }^{125} \mathrm{I}-$ chicken insulin and ${ }^{125} \mathrm{I}$-porcine insulin was 0.87 and $0.92 \%$ of total radioactivity when normalized at $10^{6}$ cells $/ \mathrm{ml}$, respectively. Both chicken and porcine insulins inhibited the binding of either ${ }^{125} \mathrm{I}$-insulin (Fig. 3). With unlabelled insulin as low as $1 \mathrm{ng} / \mathrm{ml}$, ${ }^{125} \mathrm{I}$-insulin binding was inhibited by $25-30 \%$. Unlabelled insulin at $100 \mathrm{ng} / \mathrm{ml}$ caused $80-90 \%$ inhibition of ${ }^{125} \mathrm{I}$-insulin binding. Throughout the range of insulin concentrations studied, chicken and porcine insulins showed similar potencies in competing with the binding of either ${ }^{125}$ I-insulin (Fig. 3). Logit transformation of the data gave significant $(\mathrm{P}<$ 0.05 ) regression lines within a concentration range $2-40 \mathrm{ng} / \mathrm{ml}$ (Fig. 3, right). 

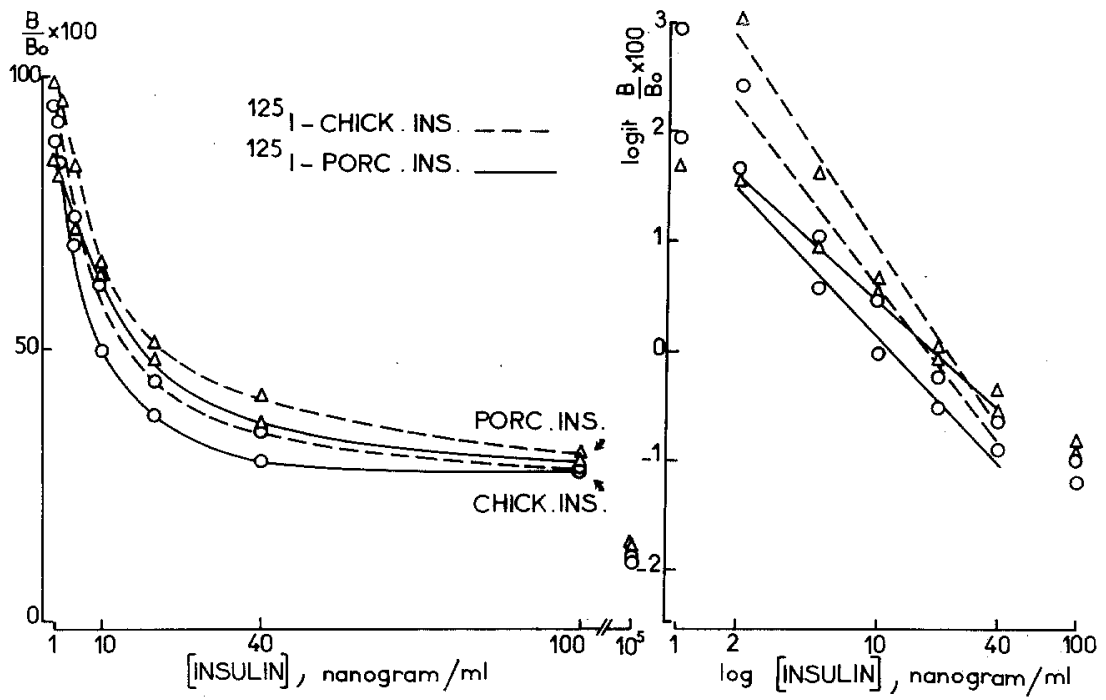

Fig. 1. Effect of chicken and porcine insulins on the binding of ${ }^{125} \mathrm{I}$-chicken insulin and ${ }^{125} \mathrm{I}$-porcine insulin (about $0.5 \mathrm{ng}$ insulin/ml) to chicken liver plasma membranes $(0.27 \mathrm{mg}$ of protein $/ \mathrm{ml})$. Binding was measured after 60 min incubation at $30^{\circ} \mathrm{C}$. The percentage of initial binding of both ${ }^{125} \mathrm{I}$-insulins $\left(\frac{\mathrm{B}}{\mathrm{B}_{0}} \times 100\right)$ to the left and its logit transformation to the right are plotted against the concentration of unlabelled insulin on an arithmetic scale (left) and on a logarithmic scale (right). Each point is the mean of duplicate aliquot samples from each incubation tube (see Materials and Methods). To the right, equations of the regression lines and correlation coefficients were: $\mathrm{y}=-2.322 \mathrm{x}+2.892, \mathrm{r}=-0.985$ (chicken insulin, 0 ) and $\mathrm{y}=-2.668 \mathrm{x}+3.631, \mathrm{r}=-0.981$ (porcine insulin, $\Delta$ ) with ${ }^{125} \mathrm{I}$-chicken insulin; $\mathrm{y}=-1.927 \mathrm{x}+2.056, \mathrm{r}=-0.988$ (chicken insulin, 0 ) and $\mathrm{y}=-1.631 \mathrm{x}+2.090, \mathrm{r}=-0.997$ (porcine insulin, $\Delta$ ) with ${ }^{125} \mathrm{I}$-porcine insulin, where $\mathrm{y}$ and $\mathrm{x}$ represent the ordinate and the abscissa, respectively

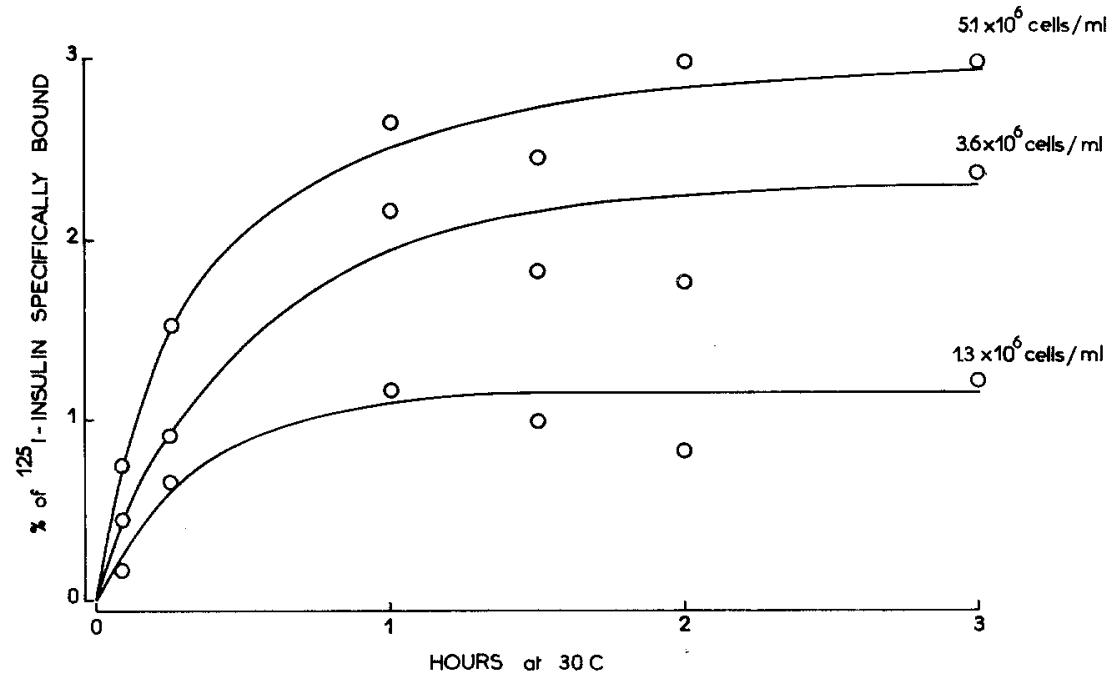

Fig. 2. Time course of specific binding of ${ }^{125}$ I-chicken insulin to chicken hepatocytes at $30^{\circ} \mathrm{C}$. At time $0,{ }^{125} \mathrm{I}$-insulin, about $0.2 \mathrm{ng} / \mathrm{ml}$, was mixed with chicken hepatocytes at the concentrations indicated in the absence or in the presence of unlabelled hormone at $100 \mu \mathrm{g} / \mathrm{ml}$. The latter was used to determine the proportion of nonspecific binding (Nonspecific binding represented $16-20 \%$ of total binding). At the indicated times, hepatocyte-bound ${ }^{125}$ I-insulin was isolated by rapid filtration on cellulose acetate (EAWP, $1.0 \mu \mathrm{m}$ ) Millipore filters as described elsewhere [32]. Each point is the mean of two determinations
Binding of Chicken and Porcine Insulin to Chicken Erythrocytes

Specific binding of ${ }^{125} \mathrm{I}$-porcine insulin was found in chicken erythrocytes which was dependent on cell concentration and on temperature. With cells at about $2.2 \times 10^{9} / \mathrm{ml}$, i. e., a concentration which is similar to that of red cells in chicken blood [35], specific binding represented about $12.4 \%$ of total ${ }^{125} \mathrm{I}$-insulin and was higher at $20^{\circ} \mathrm{C}$ than at $30^{\circ} \mathrm{C}$
(Table 2), as observed in other insulin-binding systems $[32,36]$. Chicken and porcine insulins were compared in their ability to compete with the binding of ${ }^{125} \mathrm{I}$-porcine insulin after $1 \mathrm{hr}$ incubation at $20^{\circ} \mathrm{C}$ (Fig. 4). Both insulins at $2 \mathrm{ng} / \mathrm{ml}$ inhibited $20 \%$ of the ${ }^{125} \mathrm{I}$-porcine insulin binding. At $100 \mathrm{ng} / \mathrm{ml}$, the binding of labelled insulin was inhibited by $55 \%$. Chicken insulin appeared more potent than porcine insulin over the range of concentration tested (Fig. 4, left). The higher potency of chicken 

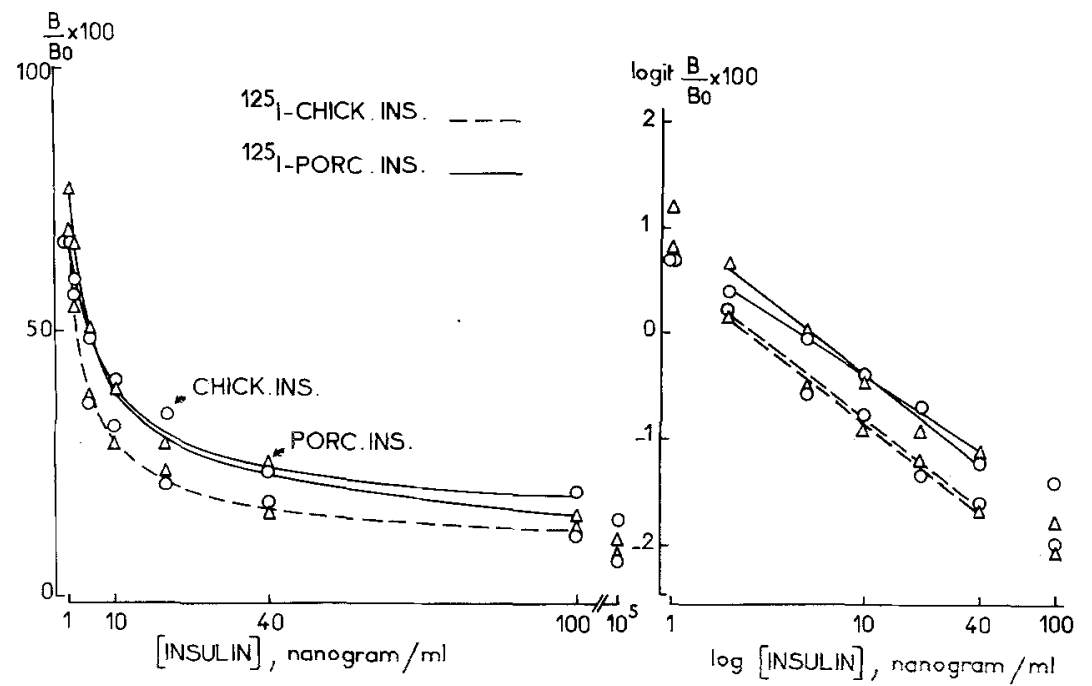

Fig. 3. Effect of chicken and porcine insulins on the binding of ${ }^{125} \mathrm{I}$-chicken insulin and ${ }^{125} \mathrm{I}$-porcine insulin (about $0.5 \mathrm{ng}$ insulin/ml) to chicken hepatocytes $\left(4.4 \times 10^{6} \mathrm{cells} / \mathrm{ml}\right)$. Binding was measured after $60 \mathrm{~min}$ incubation at $30^{\circ} \mathrm{C}$. The percentage of initial binding of both ${ }^{125} \mathrm{I}$-insulins $\left(\mathrm{B}_{\mathrm{B}_{0}}^{\mathrm{B}} \times 100\right)$ to the left and its logit transformation to the right are plotted against the concentration of unlabelled insulin on an arithmetic scale (left) and on a logarithmic scale (right). Each point is the mean of triplicate determination. To the right, equations of the regression lines and correlation coefficients were: $y=-1.402 x+0.585, r=-0.986$ (chicken insulin, 0 ) and $y=-$ $1.387 \mathrm{x}+0.539, \mathrm{r}=-0.994$ (porcine insulin, $\Delta$ ) with ${ }^{125}$ I-chicken insulin; $\mathrm{y}=-1.167 \mathrm{x}+0.765, \mathrm{r}=-0.994$ (chicken insulin, 0 ) and $\mathrm{y}=-1.431 \mathrm{x}+1.039, \mathrm{r}=-0.993$ (porcine insulin, $\Delta$ ) with ${ }^{125} \mathrm{I}$-porcine insulin, where $\mathrm{y}$ and $\mathrm{x}$ represent the ordinate and the abscissa, respectively
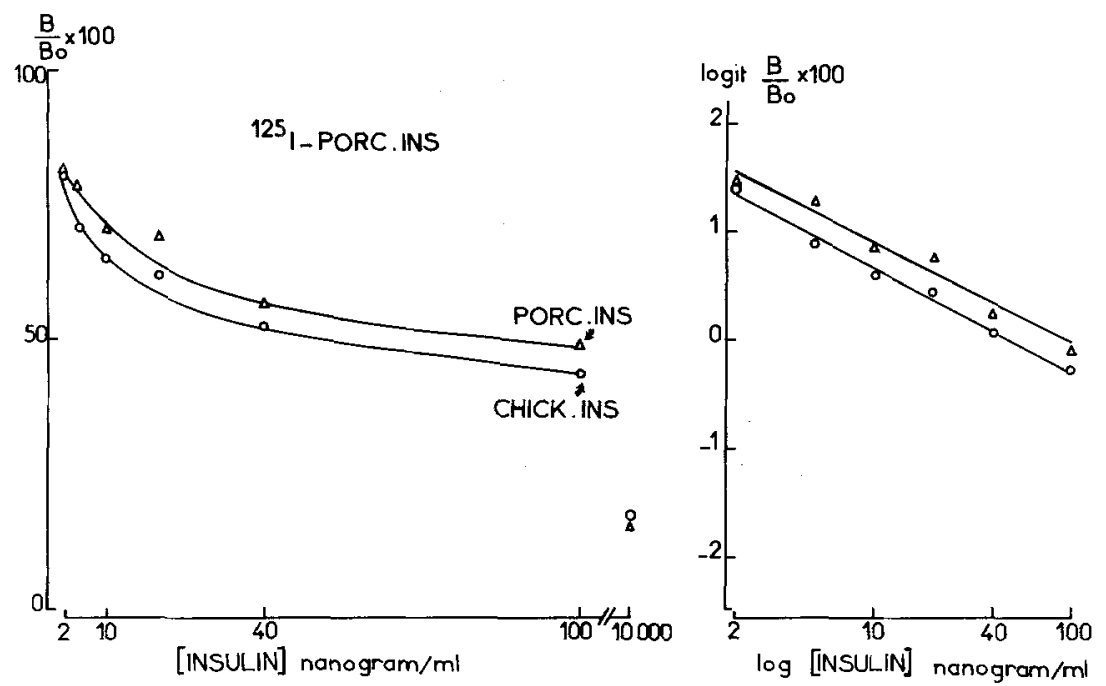

Fig. 4. Effect of chicken and porcine insulins on the binding of ${ }^{125} \mathrm{I}$-porcine insulin (about $0.2 \mathrm{ng}$ insulin $/ \mathrm{ml}$ ) to chicken erythrocytes (about $1.2 \times 10^{9} \mathrm{cells} / \mathrm{ml}$ of incubation medium). Binding was measured after $60 \mathrm{~min}$ incubation at $20^{\circ} \mathrm{C}$. The percentage of initial binding of ${ }^{125}$ I-porcine insulin $\frac{B}{B_{0}} \times 100$ ) to the left and its logit transformation to the right are plotted against the concentration of unlabelled insulin on an arithmetic scale (left) and on a logarithmic scale (right). Each point is the mean of duplicate aliquot samples from each incubation tube. To the right, equations of the regression lines and correlation coefficients were $\mathrm{y}=-0.957 \mathrm{x}+1.632, \mathrm{r}$ $=-0.993$ with chicken insulin, and $\mathrm{y}=$ $-0.924 x+1.829, r=-0.984$ with porcine insulin, where $y$ and $x$ represent the ordinate and the abscissa, respectively

insulin was significant $(\mathrm{P}<0.01)$ after logit transformation of the data (Fig. 4, right).

\section{Apparent Number of Insulin-Binding Sites in Chicken Tissues}

If we assume that the steady state of binding which is achieved by $60 \mathrm{~min}$ approximates equilibrium conditions, the plot shown in Figure 5 (MichaelisMenten type) gives the amount of insulin bound over a wide range of hormone concentration. However, because it is difficult to ascertain where true saturation occurs from this type of plot, Scatchard
Table 2. Effect of temperature and cell concentration on the specific binding of ${ }^{125} \mathrm{I}$-porcine insulin to chicken erythrocytes

\begin{tabular}{|c|c|c|c|}
\hline \multirow[t]{2}{*}{ Cell concentration } & \multirow[t]{2}{*}{$\begin{array}{l}\text { Temperature } \\
\left({ }^{\circ} \mathrm{C}\right)\end{array}$} & \multicolumn{2}{|c|}{$\begin{array}{l}\text { Per cent of } \\
{ }^{125} \text { I-porcine } \\
\text { insulin bound } \\
\text { after }\end{array}$} \\
\hline & & $1 \mathrm{~h}$ & $3 \mathrm{~h}$ \\
\hline $\begin{array}{l}\text { Blood concentration } \\
\text { (about } 2.2 \times 10^{9} \text { cells } / \mathrm{ml} \text { ) }\end{array}$ & $\left.\begin{array}{l}20 \\
30\end{array}\right\}$ & $\begin{array}{l}12.0 \\
10.3\end{array}$ & $\begin{array}{r}11.5 \\
5.1\end{array}$ \\
\hline $\begin{array}{l}\text { Dilution } 1 / 10 \\
\text { (about } 0.2 \times 10^{9} \text { cells } / \mathrm{ml} \text { ) }\end{array}$ & $\left.\begin{array}{l}20 \\
30\end{array}\right\}$ & $\begin{array}{l}1.3 \\
1.0\end{array}$ & $\begin{array}{l}- \\
-\end{array}$ \\
\hline
\end{tabular}




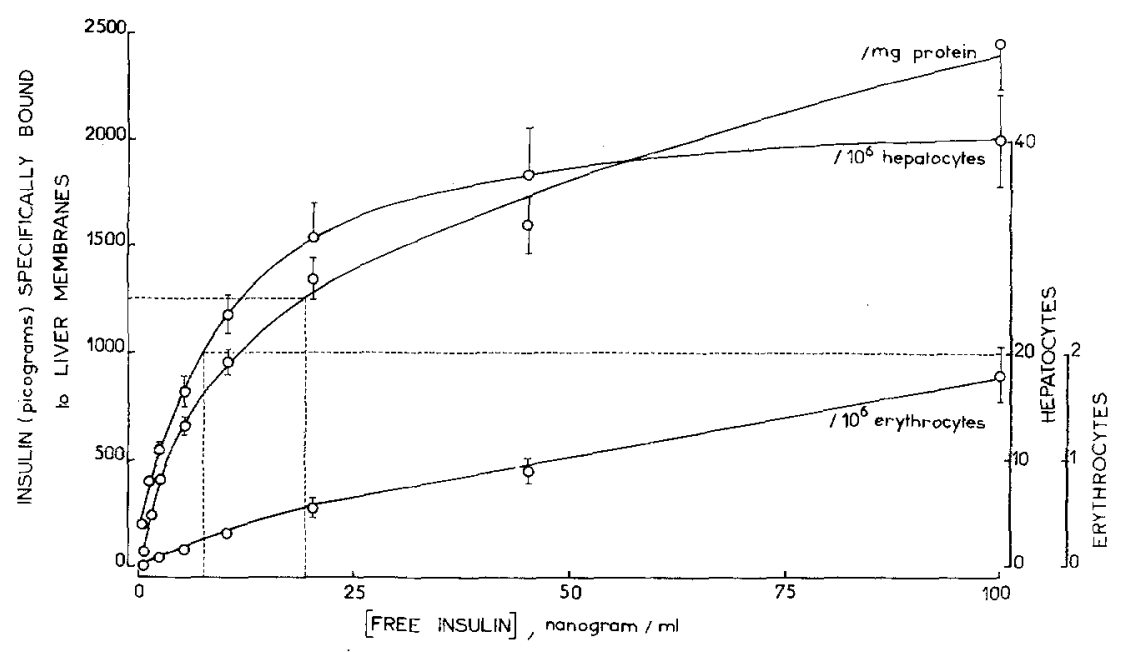

Fig. 5. Binding of insulin as a function of the free hormone concentration. The amounts of insulin specifically bound (mean \pm one SEM) were calculated from competitive binding studies in which ${ }^{125} \mathrm{I}$-porcine insulin or ${ }^{125} \mathrm{I}$-chicken insulin were mixed with increasing concentrations of unlabelled insulins. The amount of insulin nonspecifically bound (i. e., the percent of ${ }^{125}$ I-radioactivity bound in the presence of 10 or $100 \mu \mathrm{g}$ unlabelled insulin $\times$ the insulin concentration) has been subtracted from each point. Since no great differences were observed in the binding of chicken or porcine insulin, data from each competitive binding curve were pooled in order to get more accurate means. Binding to chicken liver plasma membranes is the mean of 9 competitive binding curves obtained with 2 membrane preparations, binding to chicken hepatocytes is the mean of 4 competitive binding curves, and binding to chicken erythrocytes is the mean of 3 competitive binding curves

and Lineweaver-Burke analyses of the data were also performed (not shown) and the results are indicated in Table 3. As could be expected, from the low level of binding of ${ }^{125} \mathrm{I}$-hormone observed in the three binding systems (liver membranes, liver cells and erythrocytes), the apparent maximal binding capacities and the corresponding number of binding sites were 3-6-fold lower in liver membranes (per $\mathrm{mg}$ of protein) and about 20 -fold lower in hepatocytes (on a per cell basis) of the chicken than in liver membranes and hepatocytes of the rat, respectively (Table 3). On the other hand, the apparent affinity of the chicken insulin receptor in isolated hepatocytes and in liver membranes (estimated from the concentration of insulin that corresponds to halfmaximal binding in Figure 5, i. e., about $1.3 \mathrm{nM}$ and $3.2 \mathrm{nM}$, respectively) was similar to that observed for the rat insulin receptor in hepatocytes (about $2 \mathrm{nM}$, see [17] and [32]) and in liver membranes (about $3 \mathrm{nM}$, see [19]). The possibility that the decreased insulin binding in chicken tissues (as compared to rat tissues) was due to a faster degradation of insulin can be ruled out since the percentage of ${ }^{125} \mathrm{I}$-hormone remaining intact in the incubation medium as measured by adsorption to talc [21], exceeded $95 \%$ under the conditions used to measure the binding of insulin. We conclude that the lower binding of insulin in the chicken (as compared to the rat) is mainly accounted for by a lower number of insulin-binding sites.

\section{Glucagon Binding in Chicken and Rat Liver Membranes}

In an attempt to see whether glucagon-binding sites were also less numerous in chicken than in rat liver membranes, glucagon and insulin binding were measured in simultaneous experiments using the same membrane preparations from chicken and rat livers (Fig. 6). Inhibition of ${ }^{125} \mathrm{I}$-glucagon binding by unlabelled glucagon was not so marked in chicken as in rat liver membranes (Fig. 6, left). Logit transformation of the data (Fig. 6, right) gave highly significant $(P<0.01)$ regression lines; but slopes differed significantly $(\mathrm{P}<0.01)$. When the amount of insulin and glucagon specifically bound were calculated from these data (Fig. 7), it was apparent that, at $5 \mathrm{ng}$ hormone/ $\mathrm{ml}$, both hormones were bound to a lesser extent by chicken than by rat liver membranes. However at $100 \mathrm{ng}$ hormone/ml, in contrast to glucagon, insulin binding remained lower in chicken than in rat liver membranes (Fig. 7). These observations therefore, suggest that the reduced insulin binding capacity observed in chicken liver membranes (as compared to rat liver membranes) is rather selective for this hormone.

\section{Discussion}

In this study we examined the specific binding of insulin in chicken target tissues. The data indicate that, as in mammals, liver plasma membranes and 
Table 3. Apparent maximal binding capacities and number of binding sites for the insulin receptor in chicken and rat tissues

\begin{tabular}{|c|c|c|c|c|c|c|c|c|c|}
\hline \multirow[t]{2}{*}{$\begin{array}{l}\text { Tissue } \\
\text { (Reference } \\
\text { Basis) }\end{array}$} & \multicolumn{3}{|c|}{$\begin{array}{l}\text { Liver membranes } \\
\text { (per mg of protein) }\end{array}$} & \multicolumn{3}{|c|}{ Hepatocytes (per cell) } & \multicolumn{3}{|c|}{ Erythrocytes (per cell) } \\
\hline & A & B & $\mathrm{C}$ & A & B & $\mathrm{C}$ & A & B & $\mathrm{C}$ \\
\hline $\begin{array}{c}\text { Chicken } \\
\text { Binding } \\
\text { capacity } \\
\text { (pmol) }\end{array}$ & 0.42 & 0.64 & 0.42 & $0.66 \times 10^{-8}$ & $0.76 \times 10^{-8}$ & ${ }^{8} 0.76 \times 10^{-8}$ & $3 \times 10^{-10}$ & $9 \times 10^{-10}$ & $6 \times 10^{-10}$ \\
\hline $\begin{array}{l}\text { Number of } \\
\text { sites }\end{array}$ & $25 \times 10^{10}$ & $38 \times 10^{10}$ & $25 \times 10^{10}$ & $4 \times 10^{3}$ & $4.6 \times 10^{3}$ & $4.6 \times 10^{3}$ & 180 & 540 & 360 \\
\hline $\begin{array}{l}\text { Rat } \\
\text { Binding } \\
\text { capacity } \\
\text { (pmol) }\end{array}$ & 2.7 & 1.5 & n.d. & $14 \times 10^{-8}$ & $16 \times 10^{-8}$ & n.d. & & & \\
\hline $\begin{array}{l}\text { Number of } \\
\text { sites }\end{array}$ & $160 \times 10^{10}$ & $90 \times 10^{10}$ & n.d. & $84 \times 10^{3}$ & $96 \times 10^{3}$ & n.d. & & & \\
\hline
\end{tabular}

Numbers under A, B, and C refer to those obtained from Michaelis Menten type plot (as in Fig. 5, assuming maximal specific binding at $100 \mathrm{ng}$ insulin/ml incubation medium), Scatchard plot, and Lineweaver Burke plot, respectively. For rat liver membranes, figures A and $\mathrm{B}$ were obtained from data in reference 19 and 36 , respectively. For rat hepatocytes, figures A and B were obtained from data in reference 17. All of these apparent numbers derive from steady state experiments, which were performed at $30^{\circ} \mathrm{C}$ with liver membranes and hepatocytes (both in the chicken and in the rat) and at $20^{\circ} \mathrm{C}$ with chicken erythrocytes

n. d.: not determined

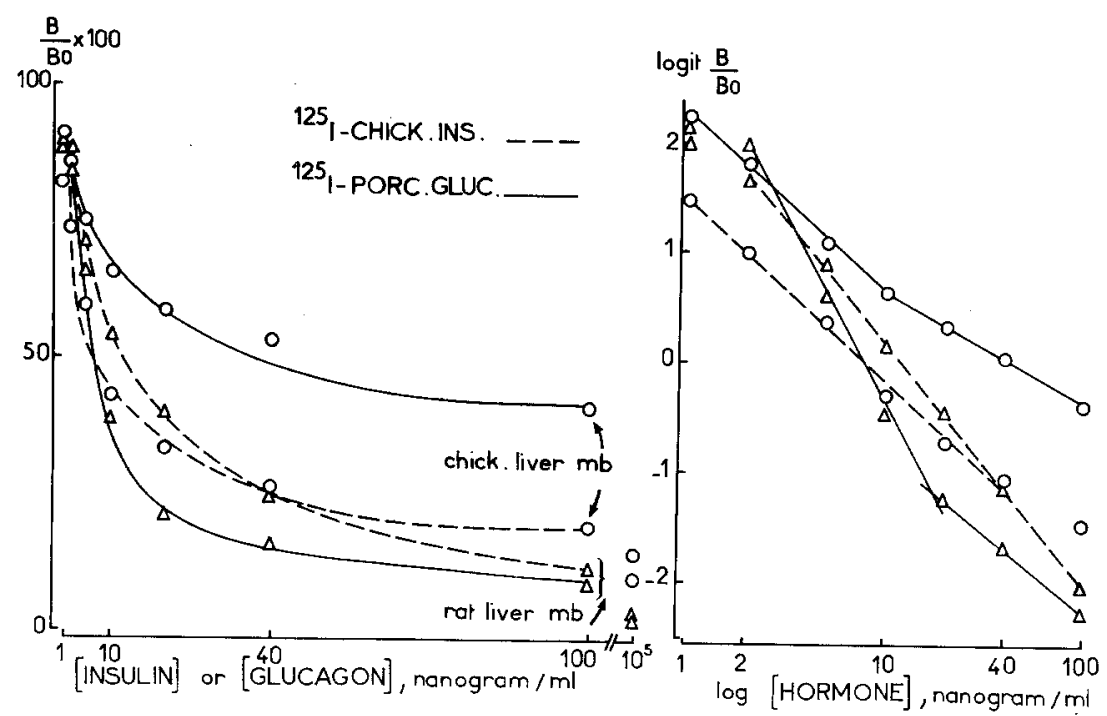

Fig. 6. Effect of chicken insulin and porcine glucagon on the binding of ${ }^{125} \mathrm{I}$-chicken insulin $(0.5 \mathrm{ng} / \mathrm{ml})$ and ${ }^{125} \mathrm{I}$-porcine glucagon $(0.1 \mathrm{ng} / \mathrm{ml})$ in chicken liver plasma membranes $(0.12 \mathrm{mg}$ of protein $/ \mathrm{ml})$ and in rat liver plasma membranes $(0.20 \mathrm{mg}$ of protein $/ \mathrm{ml})$. Insulin binding was measured after $60 \mathrm{~min}$ incubation at $30^{\circ} \mathrm{C}$ and glucagon was measured after 30 min incubation at $30^{\circ} \mathrm{C}$. The percentage of initial binding of ${ }^{125} \mathrm{I}$-insulin and ${ }^{125} \mathrm{I}$-glucagon $\left(\frac{\mathrm{B}}{\mathrm{B}_{0}} \times 100\right)$ to the left and its logit transformation to the right are plotted against the concentration of unlabelled hormones on an arithmetic scale (left) and on a logarithmic scale (right). Each point is the mean of duplicate aliquot samples from each incubation tube. Initial bindings expressed as \% total radioactivity and normalized at $0.10 \mathrm{mg}$ of protein/ml were: 2.71 ( ${ }^{125} \mathrm{I}$-chicken insulin) and 5.54 ( ${ }^{125} \mathrm{I}$-porcine glucagon) in chicken liver membranes, and 6.88 (25I-chicken insulin) and 15.53 ( ${ }^{125} \mathrm{I}$-porcine glucagon) in rat liver plasma membranes. To the right, equations of the regression lines and correlation coefficients were: $\mathrm{y}=-1.609 \mathrm{x}+1.454, \mathrm{r}=-0.997$ in the concentration range $1-40 \mathrm{ng} / \mathrm{ml}\left({ }^{125}\right.$ I-chicken insulin), $\mathrm{y}=-1.617 \mathrm{x}+2.265$, $\mathrm{r}=-0.999$ in the concentration range $1-10 \mathrm{ng} / \mathrm{ml}$ and $\mathrm{y}=-1.003 \mathrm{x}+1.674, \mathrm{r}=-0.996$ in the concentration range $10-100 \mathrm{ng} / \mathrm{ml}$ ( ${ }^{125} \mathrm{I}$-porcine glucagon) in chicken liver membranes; and $\mathrm{y}=-2.191 \mathrm{x}+2.392, \mathrm{r}=-0.999 \mathrm{in}$ the concentration range $2-100 \mathrm{ng} / \mathrm{ml}$ ( ${ }^{125} \mathrm{I}$-chicken insulin), $\mathrm{y}=-3.315 \mathrm{x}+2.979, \mathrm{r}=-0.997$ in the concentration range $2-20 \mathrm{ng} / \mathrm{ml}$ and $\mathrm{y}=-1.471 \mathrm{x}+0.684, \mathrm{r}=-$ 0.999 in the concentration range $20-100 \mathrm{ng} / \mathrm{ml}$ ( ${ }^{125} \mathrm{I}$-porcine glucagon) in rat liver membranes. $\mathrm{y}$ and $\mathrm{x}$ represent the ordinate and the abscissa respectively 


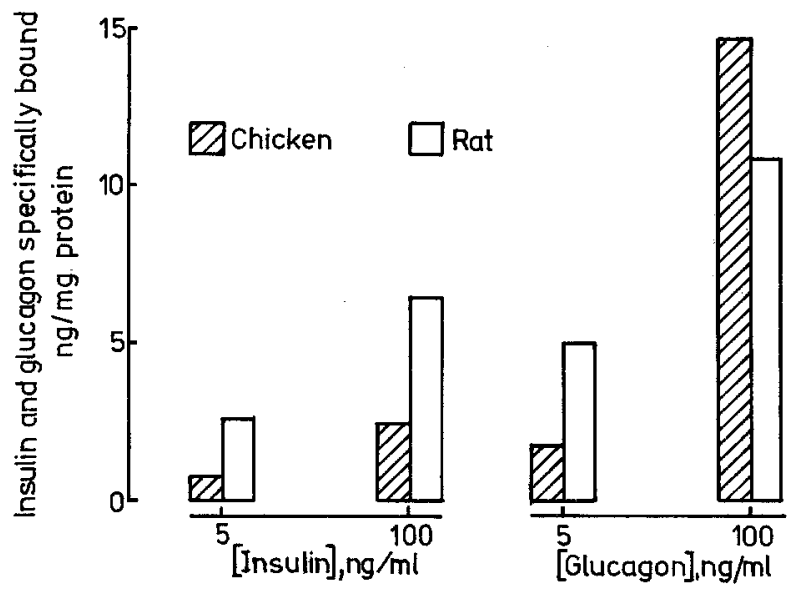

Fig. 7. Specific binding of chicken insulin and porcine glucagon in chicken and rat liver membranes as a function of hormone concentrations. These data were calculated from binding studies presented in Fig. 6

liver cells of the chicken possess specific insulinbinding sites with the properties (specificity, affinity and saturability) of biologically important receptors to the hormone. The results reported here also demonstrate the presence of specific insulin-binding sites in chicken erythrocytes. The insulin receptor has recently been characterized in erythrocyte membranes [28] and in intact erythrocytes [29] from the turkey.

Our results indicate that insulin receptors are less numerous in the chicken liver than in the rat liver. Since this was observed with ${ }^{125} \mathrm{I}$-chicken insulin as well as with ${ }^{125} \mathrm{I}$-porcine insulin, one can ascertain that the difference is related to chicken insulin receptors and not to the structural differences between chicken and porcine insulins. The lower insulin-binding in the chicken (as compared to the rat) was observed both in purified liver plasma membranes (per mg of membrane protein) and in isolated hepatocytes (on a per cell basis). Since the liver cell of the chicken (diameter: $12 \mu \mathrm{m}$, [24] is smaller than that of the rat (diameter: $23 \mu \mathrm{m}$, [24], a decrease in the number of insulin binding sites per cell would not necessarily result in a decrease in the density of the sites on the cell surface. Assuming that the isolated liver cell is a sphere, one can calculate, from the measurements of insulin binding in isolated chicken and rat hepatocytes (Table 3), that the number of insulin receptors per unit surface area is approximately 5-fold lower in the chicken (about 10 sites $/ \mu \mathrm{m}^{2}$ ) than in the rat (about $50 \mathrm{sites} / \mu \mathrm{m}^{2}$ ) liver cell. This agrees remarkably well with the 3-6-fold difference between the number of insulinbinding sites in the plasma membrane fraction of chicken and rat livers. In contrast to the marked difference in the number of sites, the apparent affinity of insulin binding in chicken hepatocytes and liver membranes was analogous to that observed in similar receptor preparations from the rat. This is in agreement with a recent study indicating that insulin receptors in turkey erythrocytes possess functional properties that are virtually identical to those of the mammalian insulin receptors [29]. These and other comparative studies suggest that the functional characteristics of the insulin receptor have remained remarkably constant despite evolutionary changes occuring in insulin structure [37]. It is indeed noteworthy that the variations in insulin binding which have thus far been reported among animal species have always been accounted for by changes in the number of binding sites (i.e., the binding capacity) rather than by alterations in the receptor affinity. For example, a higher insulin-binding capacity $[17,38]$ appears to be responsible for the higher binding of ${ }^{125} \mathrm{I}$-porcine insulin to liver membranes [17, 38] and various tissues [39] of the guinea pig when compared to the rat.

In view of our previous finding that chicken insulin had a higher binding affinity than porcine insulin in rat liver membranes $[14,15]$, it would have been expected that chicken insulin would also exhibit a higher potency in binding to the chicken insulin receptor. This was not consistently observed, possibly because the level of insulin binding was too low, particularly in chicken hepatocytes, to permit discrimination between the binding potencies of the two insulins.

That chicken liver cells are equipped with insulin receptors that are less numerous than (although qualitatively similar to) those present in rat liver cells may provide some explanation for the physiological state of relative insulin resistance which has been reported in the chicken. It is clear, from our results, that the decrease in insulin binding is observed whether the data are expressed per whole cell, per unit of cell surface area, or per mg of cell plasma membrane protein. This is a situation analogous to that observed in the obese hyperglycaemic $(o b / o b)$ mouse when compared to the nonobese mouse (for review, see [17]), a model of genetic obesity in which insulin resistance has been well documented. It may be anticipated that such a decrease in the concentration of insulin receptors will decrease the sensitivity of the target cell to insulin [17]. One may also speculate that the 2-fold higher binding affinity and biological potency [14] of chicken insulin (compared to porcine insulin) will not be sufficient to counterbalance a 5-fold lower density of insulin receptors in chicken cells. Therefore, there is a possibility that this decreased number and/or-concentration of insulin receptors in chicken cells is involved, partly at least, in some of 
the peculiarities of carbohydrate metabolism in the chicken, e.g., basal hyperglycaemia and relative insulin resistance. The low glucose content and glucose utilization in chicken erythrocytes [40] may also be relevant to this aspect. Studies aimed at relating insulin binding and insulin action in chicken tissues are certainly warranted.

Acknowledgements. The excellent technical assistance of $D$. Huy Bon Hoa and M.C. Chamblier is greatly acknowledged. This work was supported in part by a grant ( $n^{\prime \prime} 72-7-0506$ ) from the Délégation Générale à la Recherche Scientifique et Technique (D. G. R.S. T.).

\section{References}

1. Hazelwood, R. L.: In: P.D. Sturkie (Ed.): Avian Physiology, 2nd edition, p. 313. Ithaca, N. Y.: Cornell University Press 1965

2. Hazelwood, R.L.: The avian endocrine pancreas. Amer. Zool. 13, 699-709 (1973)

3. Goodridge, A.G., Ball, E. G.: Lipogenesis in the pigeon: in vivo studies. Am. J. Physiol. 213, 245-249 (1967)

4. Leveille, G. A., O’Hea, E.K., Chakrabarty, K.: In vivo lipogenesis in the domestic chicken. Proc.Soc. Exp. Med. 128, 398-401 (1968)

5. Goodridge, A.G.: Metabolism of glucose- $\mathrm{U}-{ }^{14} \mathrm{C}$ in vitro in adipose tissue from embryonic and growing chicks. Am. J. Physiol. 214, 897-901 (1968)

6. Langslow, D.R., Hales, C. N.: Lipolysis in chicken adipose tissue in vitro. J. Endocrinol 43, 285-294 (1969)

7. Hazelwood, R.L., Kimmel, J.R., Pollock, H. G.: Biological characterization of chicken insulin activity in rats and domestic fowl. Endocrinology 83, 1331-1336 (1968)

8. Langslow, D. R., Freeman, B.M.: Partial pancreatectomy and the role of insulin carbohydrate metabolism in Gallus Domesticus. Diabetologia 8, 206-210 (1972)

9. Miahle, P.: Glucagon, insuline et régulation endocrine de la glycémie chez le canard. Acta Endocrinol. (Kbh) Suppl. 36, 8-134 (1958)

10. Desbals, P.: Effets de la pancréatectomie et de l'hypophysectomie sur la circulation des lipides chez le canard. Doctoral Thesis, University of Toulouse, France 1972

11. Langslow, D.R., Butler, E.J., Hales, C.N., Pearson, A.W.: The response of plasma insulin, glucose and nonesterified fatty acids to various hormones, nutrients and drugs in the domestic fowl. J.Endocrinol 46, 243-260 (1970)

12. Rahcja, K.L., Tepperman, H.M., Tepperman, J.: Effect of diet on plasma insulin and glucose levels of newly hatched chicks. Horm. Metab. Res. 4, 69-73 (1972)

13. Raheja, K.L., Tepperman, H.M., Tepperman, J.: Effect of fasting and high-fat diet feeding on plasma and pancreatic insulin contents in young chick given an oral glucose load. Horm. Metab. Res. 4, 337-341 (1972)

14. Simon, J., Freychet, P., Rosselin, G.: Chicken insulin: radioimmunological characterization and enhanced activity in rat fat cells and liver plasma membranes. Endocrinology 95, 1439-1449 (1975)

15. Simon, J., Freychet, P., Rosselin, G., De Meyts, P.: Enhanced binding affinity of chicken insulin for receptors in rat liver membranes and human lymphocytes: relationship to the kinetic properties of the hormone-receptor interaction. Endocrinology 100, 115-121 (1977)

16. Weitzel, G., Renner, R., Kemmler, W., Rager, K.: Struktur und erhöhte Aktivität des Insulins vom Truthahn ( $\mathrm{Me}$ leagris gallopavo). Hoppe Scylers Z. Physiol. Chem. 353, 980-986 (1972)

17. Freychet, P.: Interactions of polypeptide hormones with cell membrane specific receptors: studies with insulin and glugacon. Diabetologia 12, 83-100 (1976)

18. Freychet, P., Roth, J., Neville, D.M. Jr.: Mono-iodo-insulin: demonstration of its biological activity and binding to fat cells and liver membranes. Biochem. Biophys. Res. Commun. 43, 400-408 (1971)

19. Freychet, P.: The interactions of proinsulin with insulin receptors on the plasma membranes of the liver. J. Clin. Invest. 54, 1020-1031 (1974)

20. Nottey, J.J., Rosselin, G.: Monoiodoglucagon: preparation, isolement, identification, contrôle radioimmunulogique. C. R. Acad. Sci. [D] (Paris) 273, 2118-2121 (1971)

21. Freychet, P., Kahn, R., Roth, J., Neville, D.M., Jr.: Insulin interactions with liver plasma membranes. Independence of binding of the hormone and its degradation. J. Biol. Chem. 247, 3953-3961 (1972)

22. Neville, D.M., Jr.: Isolation of an organ specific protein antigen from cell-surface membrane of rat liver. Biochim. Biophys. Acta 154, 540-552 (1968)

23. Rosselin, G., Freychet, P.: Basal and hormone-stimulated adenylate cyclase in liver plasma membranes: measurement by radioimmunoassay of cyclic AMP. Biochim. Biophys. Acta 304, 541-551 (1973)

24. Capuzzi, D.M., Rothman, V., Margolis, S.: The regulation of lipogenesis by cyclic nucleotide in intact hepatocytes prepared by a simplified technique. J. Biol. Chem. 249, 1286-1294 (1974)

25. Bilezikian, J.P., Aurbach, G.D.: A $\beta$-adrenergic receptor of the turkey erythrocyte. 1 . Binding of catecholamine and relationship to adenylate cyclase activity. J. Biol. Chem. 248, 5577-5583 (1973)

26. Gavin, J.R., Roth, J., Jen, P., Freychet, P.: Insulin receptors in human circulating cells and fibroblasts. Proc. Natl. Acad. Sci. USA 69, 747-751 (1972)

27. Lowry, O.H., Rosebrough, N.J., Farr, A.L., Randall, R.J.: Protein measurement with the Folin phenol reagent. J. Biol. Chem. 193, 265-275 (1951)

28. Ginsberg, B.H., Kahn, C.R., Roth, J.: The insulin receptor of the turkey erythrocyte. Characterization of the membrane-bound receptor. Biochim. Biophys. Acta 443, 227-242 (1976)

29. Ginsberg, B.H., Kahn, C. R., Roth, J.: The insulin receptor of the turkey erythrocyte; similarity to mammalian insulin receptors. Endocrinology (in press 1977)

30. Freychet, P., Roth, J., Neville, D.M., Jr.: Insulin receptors in the liver: specific binding of ${ }^{125}$ I-insulin to the plasma membrane and its relation to insulin bioactivity. Proc. Natl. Acad. Sci. USA 68, 1833-1837 (1971)

31. Bataille, D., Freychet, P., Rosselin, G.: Interactions of glucagon, gut glucagon, vasoactive polypeptide and secretin with liver and fat cell plasma membranes: binding to specific sites and stimulation of adenylate cyclase. Endocrinology 95, 713-721 (1974)

32. Freychet, P., Rosselin, G., Rancon, F., Fouchereau, M., Broer, Y.: Interactions of insulin and glucagon with isolated rat liver cell. 1. Binding of the hormones to specific receptors. Horm. Metab. Res. (S. A. Berson memorial issue), Suppl. 5, 72-78 (1974) 
33. Cuatrecasas, P.: Insulin-receptor interactions in adipose tissue cells: direct measurement and properties. Proc. Natl. Acad. Sci. USA 68, 1264-1268 (1971)

34. Snedecor, G.W., Cochran, G.W.: Statistical Methods, ed 5. Iowa: The Iowa State College Press 1956

35. Freeman, B.M.: In: D. J. Bell, B.M. Freeman (Eds.): Physiology and biochemistry of the domestic owl, vol 2, p. 841. London, New York: Academic Press 1971

36. Kahn, C. R., Freychet, P., Roth, J., Neville, D.M., Jr.: Quantitative aspects of the insulin-receptor interaction in liver membranes. J. Biol. Chem. 249, 2249-2257 (1974)

37. De Meyts, P., Kahn, C.R., Ginsberg, B., Roth, J.: The insulin receptor: greater evolutionary stability than insulin. Diabetes 24 (Suppl. 2), 393 (1975)

38. Freychet, P.: Insulin reccptors: implications and applications. In: A.E. Hoechst, Renold (Eds.): Proceedings of the 12th Symposium Medicum. Stuttgart: Schattauer (in press 1977)
39. Posner, B. I., Kelly, P. A., Shin, R.P.C., Friesen, H. G.: Studies of insulin, growth hormone and prolactin binding; tissue distribution, species variation and characterization. Endocrinology 95, 521-531 (1974)

40. Bell, D. J.: In: D. J. Bell, B.M. Frecman (Eds.): Physiology and Biochemistry of the Domestic Fowl, vol 2, p. 863. London, New York: Academic Press 1971

Received: September 6, 1976, and in revised form:

January 14, 1977

J. Simon, M. D.

Station de Recherches

Avicoles, INRA

B.P.N. 1

F-37380 Nouzilly

France 